\title{
THE STYLISTIC CATEGORY OF CLARITY (इAФHNEIA, EXPLANATIO, PERSPICUITAS, CLARITAS) IN THE EYES OF GREEK AND ROMAN WRITERS
}

ABSTRACT: The concept of clarity and the closely related idea of colour were of great importance not only for the formulation of classical ideas connected with the theory of beaux arts, but also for the creation of concepts related to the ancient academic and philosophical discourse, mainly via the use of light/shadow/ colour metaphors to express and envisage the problems discussed. These were of special importance for what is commonly referred to as ancient literary aesthetics, which is the product of ideas originating in classical philosophical literary theory, practice and critique. It is to this very area of aesthetic and literary meanings of clarity that I would like to devote the present paper. However, the bulk of preserved testimonies, both direct (i.e. directly and normatively formulated) and indirect (i.e. resulting from the immanent poetics of the work), as well as the fact that they are multi-layered, compel me to narrow my analysis to the concept of clarity ( $\sigma \alpha \varphi \eta ́ v \varepsilon i \alpha$, claritas) as a stylistic category in ancient rhetoric and poetics, based exclusively on concepts expressed by classical Greek and Latin authors.

KEY WORDS: clarity, perspicuity, stylistic category, literary aesthetics, ancient rhetoric, ancient poetics, artistic style, stylistic decorum

The concept of clarity is naturally related to the sufficient amount of light ( $\varphi \tilde{\omega} \zeta$, lux, lumen), which renders an object possible to be seen and known clearly. However, the feeling of clarity as a phenomenon leading 
to the perception of the object, is not only connected with the external characteristics of the said object, but also related to its structure and form, filled with harmonious and proper convenientia partium; the latter is understood as a commensurate and proper relation of its parts to each other. This phenomenon results in perspicuity (perspicuitas). If perspicuity is a natural, physical and permanent state of the phenomenon, it is called substantial clarity (perspicuitas/claritas substantialis), which traditional aesthetics identifies with natural beauty. If, however, it is a form artificially created, if it is an opus aritificiosum, a work of art, then we are dealing with accidental clarity (perspicuitas/claritas accidentalis). ${ }^{1}$

Also the concept of colour $(\chi \rho \tilde{\omega} \mu \alpha$, color $)$ is intrinsically connected with light. Today we know that colour is, in fact, light divided into waves of different length. The main factor influencing our perception of colours is the spectral composition of the light, as well as other features such as the amount of light energy or personal qualities of the observer. There is a common consensus, however, that clarity denotes an abundance of light which allows us to see the colour of objects. Not enough light can

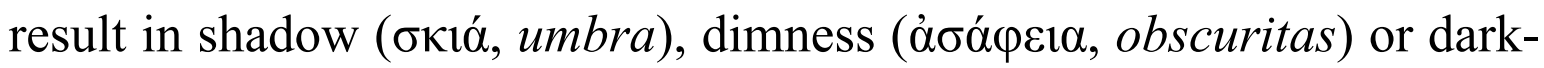

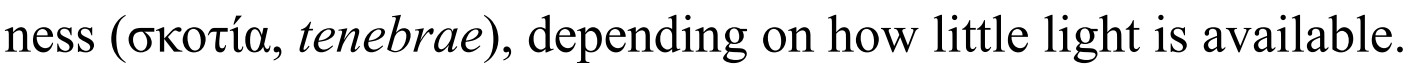

The concept of clarity and the idea of colours, closely related to it, were of great importance not only for the formulation of classical ideas connected with the theory of beaux arts, but also for the creation of concepts related to the ancient academic and philosophical discourse, mainly via the use of light/shadow/colour metaphors to express and envisage the problems discussed. These were of special importance for what is commonly referred to as ancient literary aesthetics, which is the product of ideas originating in classical philosophical literary theory, practice and critique. ${ }^{2}$ It is to this very area of aesthetic and literary meanings of clarity that I would like to devote the present paper. However, the bulk of preserved testimonies, both direct (i.e. directly and normatively formulated) and indirect (i.e. resulting from the immanent poetics of the work), as well as the fact that they are multi-layered, compel me to narrow my analysis to the concept of clarity ( $\sigma \alpha \varphi \eta ́ v \varepsilon ı \alpha$, claritas) as a stylistic category in ancient rhetoric and poetics, based exclusively on concepts

See Tatarkiewicz 1976: 136ff.

2 See O'Callaghan 1960: 161ff; Vatri 2017: cap. 4.1: The domains of clarity. 
expressed by classical Greek and Latin authors. ${ }^{3}$ Due to space constraints I will not deal with the ideas of post-classical and late ancient writers. I will also have to exclude the fascinating problem of literary use of colours, associated with the polychromatic stylistics and poetics (gemmeus stilus), which is especially prominent in ancient epideictic orations and in mannerist poetry of late Roman antiquity, both of which are characterized by prominent use of ekphrasis ${ }^{4}$ together with the tendency towards anaesthetic effect of vividness (غ่vó $\rho \gamma \varepsilon 1 \alpha$, evidentia). ${ }^{5}$ The presence, in general, of the category of clarity in both the literary and aesthetic as well as the linguistic and stylistic dimensions will be the subject matter of my more detailed study which I plan to write in the near future.

In everyday language the concept of clarity of speech is treated as part of the clear mind (mens clara), understood as logical and clear reasoning together with proper moderation in expression; the two, combined together, lead to natural and direct understanding of what is being communicated. When treated as a part of the artistic and stylistic sphere, clarity is a crucial feature of the mature style, elaborated and formed, as it is typical in our cultural sphere under the influence of Plato and Aristotle, to resemble a living being with its harmoniously formed limbs. The aim is in both cases identical: the need to be accepted and to convince the audience, which should result from the clear understanding of the source's communication. Clarity of speech can be compared here to natural clarity: it allows one to see and yet itself remains unseen, it is a consequence of clear and ordered discourse, of proper and moderate use of words and of the speaker's unique ability to convey ideas present in the speech. As such, it fulfils a well-known ancient maxim: artis est artem tegere. ${ }^{6}$ In such a context the lack of clarity is the most serious mistake possible. It is commonly understood as lack of clear and proper thinking on the speaker's part, resulting in wrongly chosen means of expression. And while it is true that the style of artistic presentation must conform to its character and literary genre, it is also obvious that in every case the main condition is to avoid unclarity.

See Lausberg 2002: 429ff.

See Webb 2009.

See Styka 2008: 102ff.

See O’Callaghan 1960: 166. 
Let us first analyse the principal Greek testimonies. The oldest expression known to us and dealing with the concept of clarity has no association with the theory of style. I discuss it here because of its age and its emphasis on the idea of clarity as a divine prerogative: $\pi \varepsilon \rho i$

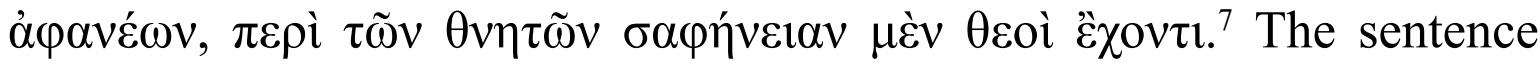
comes from the writings of Alcmeon of Croton, the student of Pythagoras, active at the end of the $6^{\text {th }}$ and the beginning of the $5^{\text {th }}$ century BCE. He was an anatomist and one of the first empirical scholars dealing with human brain. Also from the Pythagorean school comes another anonymous statement, or, in this case, a warning that one should speak clear,

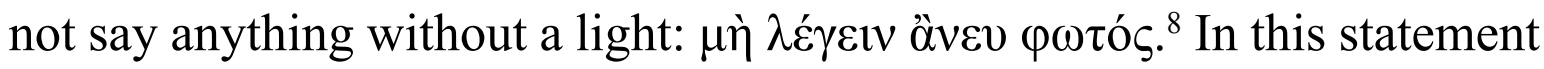
some relation to the way of speaking and to style can already be detected.

When discussing Plato's ideas on style and aesthetics, let us remind the reader about the statement in the Phaedrus defining the aforementioned rule of creating clear style of speech as similar to a harmoni-

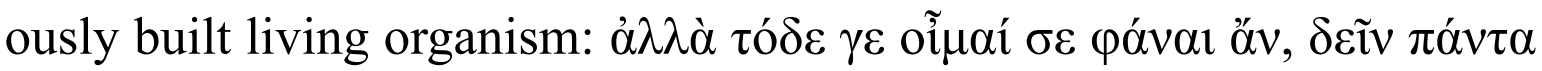

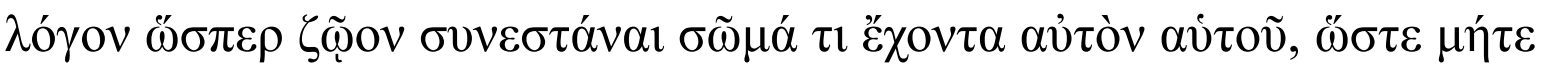

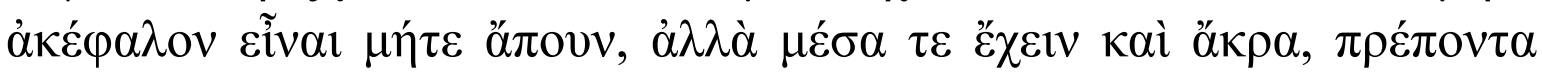

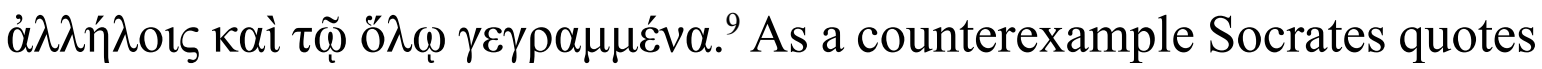
in the dialogue an ekphrastic epigram allegedly inscribed on the grave of king Midas in Phrygia. It does not matter for the understanding of this funerary inscription where in the text one starts reading. This creates a peculiar effect of clarity à rebours:

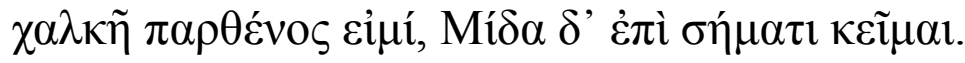

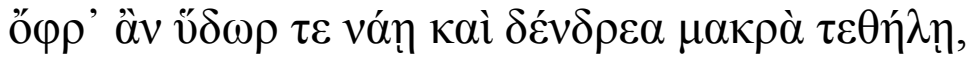

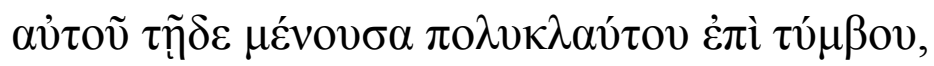

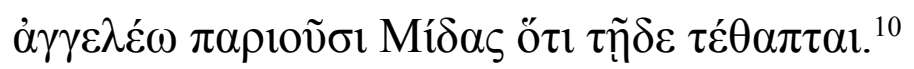

The transparent and clear style, which is a result of proper sentence structure, is explained by Plato in the subsequent chapter. Firstly one should present the main problem in the form of a condensed overview.

See Diels 1934: 24 B 1.

See Diels 1934: 58 C 4.

See Plat. Phaedr. 264c.

10 See Plat. Phaedr. 264d. See also Styka 1998: 34f. 
This should be followed by the elucidation of details, focusing on the definition of the main concepts: what is what. Such a way of proceeding would make the presentation clear and internally consistent: $\varepsilon i \varsigma$

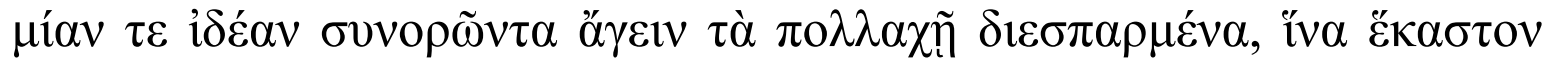

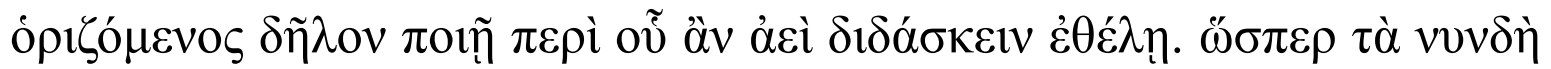

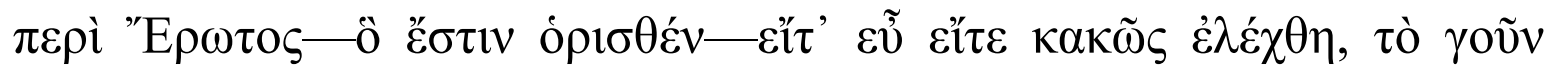

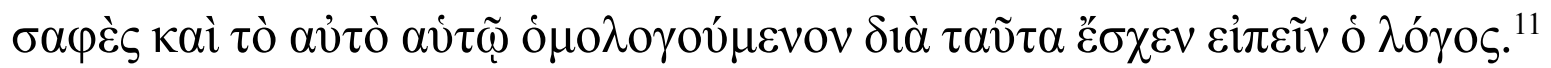

A different concept of the clarity of speech as a result of proper lexical choices is presented by Plato in the Apology. There Socrates states that he would tell the truth and truth alone and that unlike his predecessors he would not use embellishments or artificially refined words; instead, he would use simple words such as they occur to him. The context suggests, however, that at the same time these words would also be clear and meaningful, precisely because they would be used to express the truth:

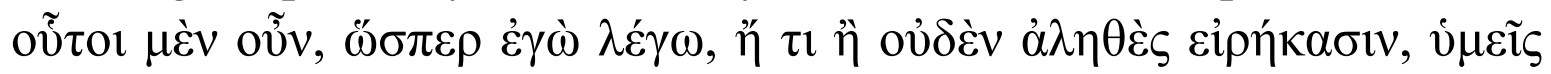

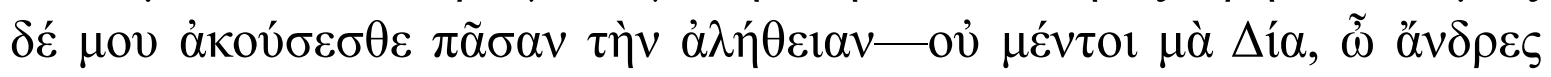

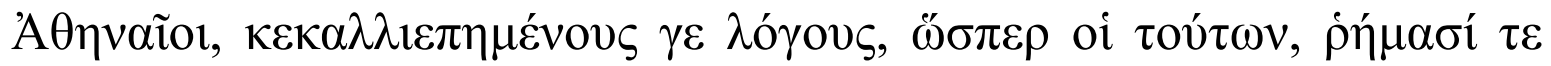

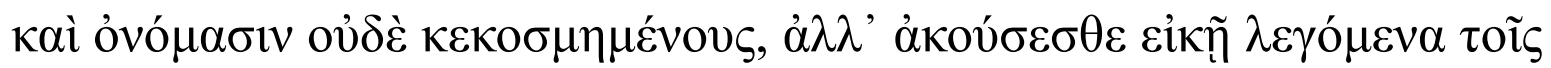

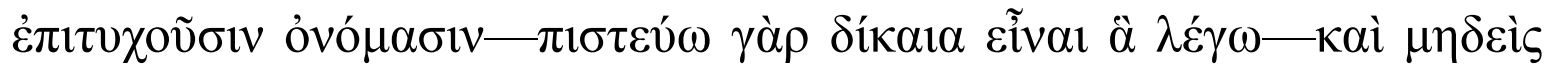
$\dot{v} \mu \tilde{\omega} \nu \pi \rho \circ \sigma \delta \circ \kappa \eta \sigma \alpha ́ \tau \omega \stackrel{\alpha}{ } \lambda \lambda \omega \varsigma_{.}{ }^{12}$

The two Platonic concepts of stylistic clarity presented above constitute a starting point of a sort for further theoretical reflections found in normative rhetorical treatises of authors such as Aristotle, pseudo-Aristotle, Cicero, Quintilian, up to the late ancient Roman grammarians. In the course of the development of the ideas of the three styles of rhetoric, of the theoretical divisions within the discipline as well as the idea of the four virtues ( $\dot{\alpha} \rho \varepsilon \tau \eta \dot{n}, v i r t u s)$ of artistic style, a concept would emerge that would place the clarity of speech ( $\sigma \alpha \varphi \eta ́ v \varepsilon 1 \alpha$, perspicuitas, claritas) within the sphere of rhetorical elocutio, proper and clear verbal expres-

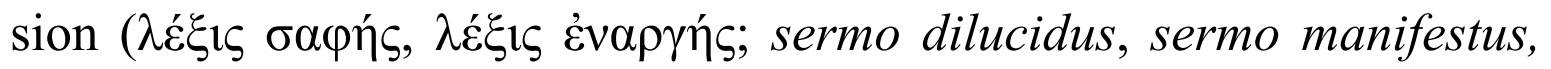
sermo distinctus). It was suggested that the clarity resides in two spheres of rhetorical action: firstly, the choice of individual words (electio verborum singulorum), and secondly, the creation of sentences and combining

\footnotetext{
11 See Plat. Phaedr. 265d.

12 See Plat. Apol. Ib-Ic, 15-22.
} 
words (verba coniuncta). ${ }^{13}$ The examples from Plato quoted here are practical solutions belonging to both aforementioned spheres: the lines from the Phaedrus to the concept of verba coniuncta, the passage from the Apology to the idea of verba singula.

In ancient literary aesthetics the notions of Aristotle are of fundamental significance, mainly because he is both pragmatic and precise in formulating them; especially his opinions on rhetoric are significant. In the third book of his normative treatise on rhetoric Aristotle discusses the style of the speech $\left(\lambda \varepsilon^{\prime} \xi 1 \zeta\right)$. Having presented his general opinions on the questions of conditions and rules of studying language and having reminded the readers of his earlier thoughts on poetical style in the Poetics, the philosopher states clearly, at the beginning of Chapter 2, that the virtue (and, by implication, the most important one) of the rhetorical

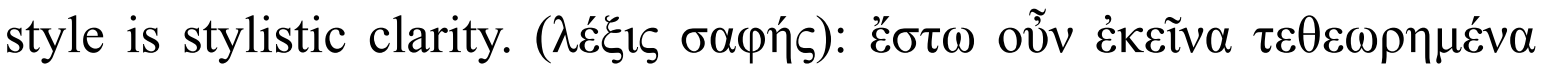

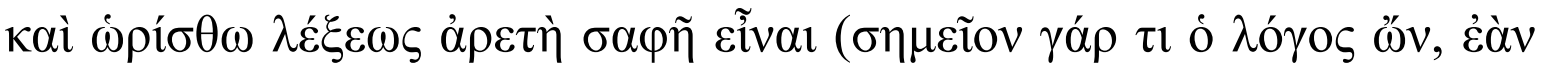

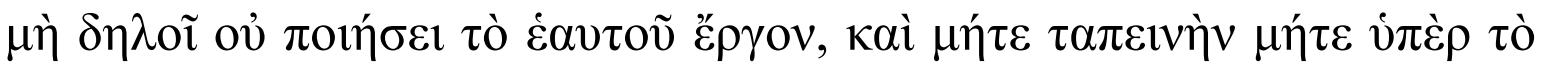

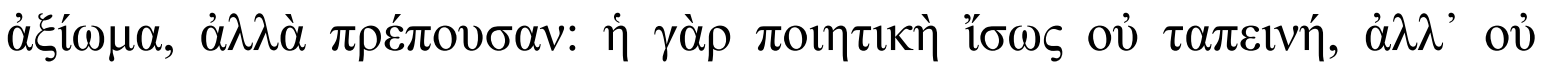
$\pi \rho \varepsilon ́ \pi 0 v \sigma \alpha \lambda \operatorname{ó}_{\gamma \omega} .^{14}$

The crucial condition necessary for achieving this kind of clarity is to follow the rule of stylistic decorum $(\pi \rho \varepsilon \dot{\pi} \pi \mathrm{v})$. It makes it possible for the speaker to avoid both unnecessary grandiosity and excessive commonness; it also makes the speech proper for its topic $(\lambda \varepsilon \dot{\varepsilon} \xi 1 \varsigma \pi \rho \varepsilon \dot{\pi} \pi 0 v \sigma \alpha)$ : $\kappa \alpha i$

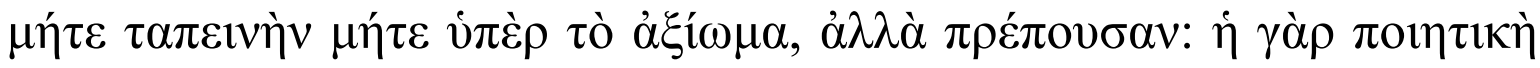

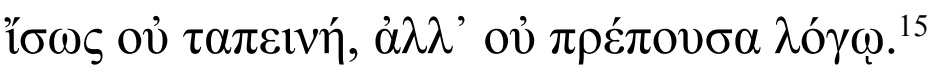

Continuing his discussion Aristotle stresses the importance of choos-

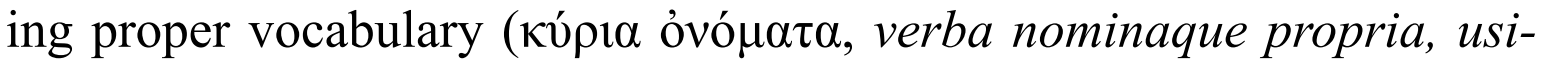
tata) to achieve the effect of clarity; he concludes that the clarity of style can be accomplished by the use of common nouns and verbs $\tau \tilde{\omega} v$

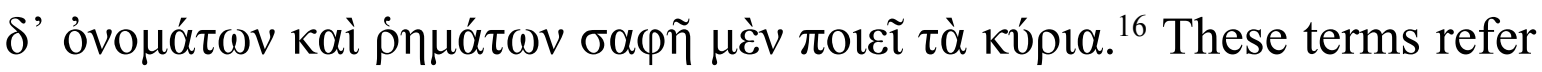
to lexical items which, albeit popularly used, possess a singular qual-

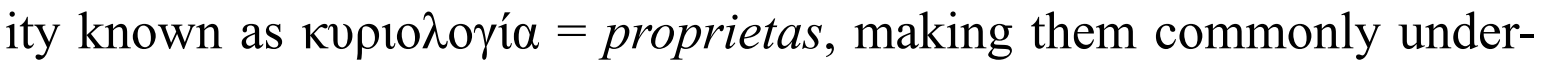
stood, because from the beginning they signify the very same thing. An explanation of the term kúpı óvó $\mu \alpha \tau \alpha$ can be found in Chapter 21 of

13 See Lausberg 2002: 306f.

14 See Aristot. $R h$. III 2, 1404b, 1-3.

15 See Aristot. Rh. III 2, 1404b, 3-4. See also Styka 1997: 12ff.

16 See Aristot. Rh. III 2, 1404b, 5-6. 


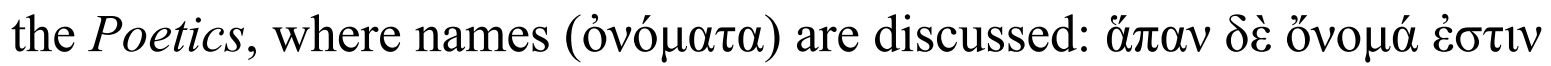

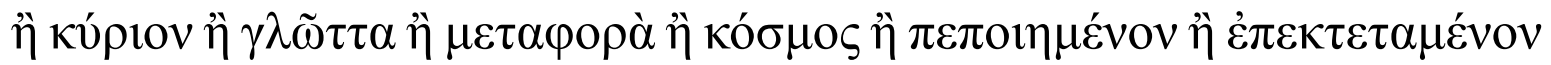

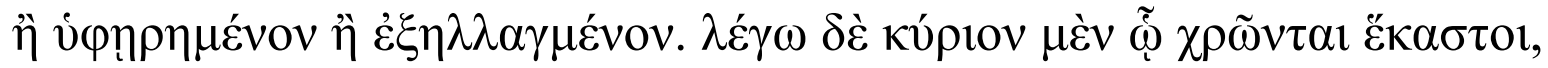
$\gamma \lambda \tilde{\omega} \tau \tau \alpha \nu \delta \dot{\varepsilon} \tilde{\omega} \tilde{\varepsilon} \tau \varepsilon \rho o l .{ }^{17}$ The need to use this kind of vocabulary is further stressed by Aristotle in Chapter 5 of Book III, discussing language correctness $-\tau$ ò $\dot{\varepsilon} \lambda \lambda \eta v i \zeta \varepsilon ı v$. Already at the very beginning the philosopher states that the basic requirement for good style is language correctness:

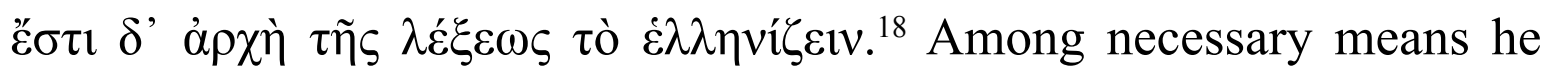
names the use of proper vocabulary: the one with correct meaning and

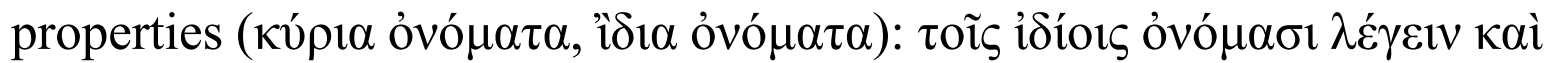

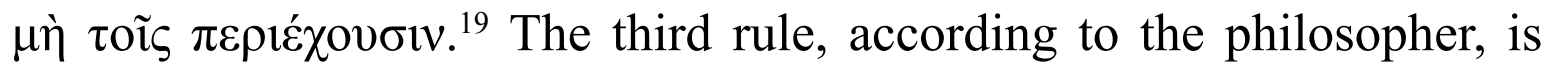
avoidance of ambiguous words, unless such is the author's intention:

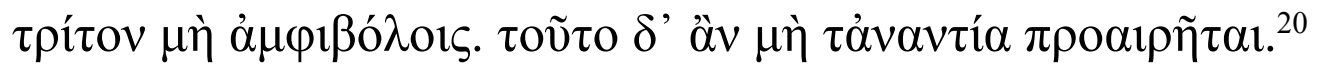

Aristotle believes that the clear style of artistic prose requires also the use of non-typical, elaborate vocabulary, typically used in poetry and discussed by him in the Poetics. The use of such vocabulary helps to avoid an impression of commonness and of being ordinary. He states that

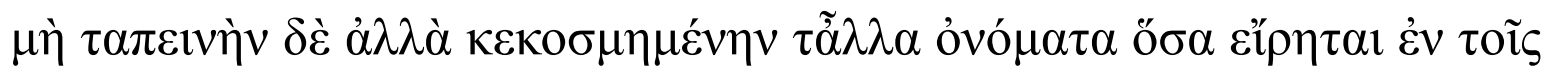

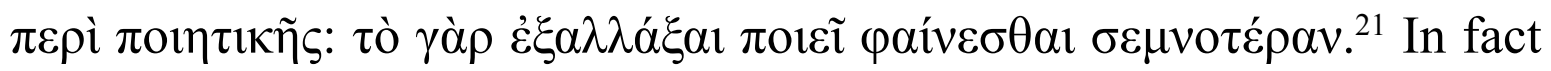
Aristotle defines here the styles of poetry and prose, using the same stylistic means: clarity and sublimity. The main difference lies in different ways of achieving these qualities and in the frequency of their use. These are, as always in Aristotle, regulated by the rules of generic propriety $(\pi \rho \varepsilon \dot{\pi} \pi v)$, with its so called relativisations, defining clearly the means and ways of proper use of the particular means of literary expressions.

Let us take a look at the features of poetic style as listed in the $\mathrm{Po}$ etics. For Aristotle the main virtues of poetic language are clarity and avoidance of the common. Language is clearest when it uses common words, but this brings about the risks of commonality. At the same time the use of atypical and rare vocabulary provides the style with gran-

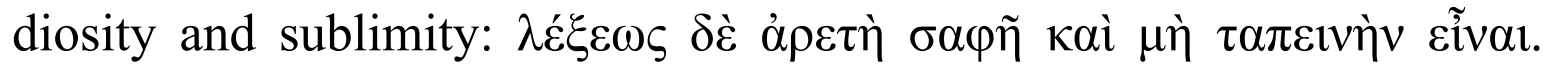

\footnotetext{
17 See Aristot. Poet. 21, 1457b, 1-4.

18 See Aristot. $R h$. III 5, 1407a, 19-20.

19 See Aristot. $R h$. III 5, 1407a, 31-32.

20 See Aristot. $R h$. III 5, 1407a, 32-33.

$21 \quad$ See Aristot. $R h$. III 2, 1404b, 6-9.
} 


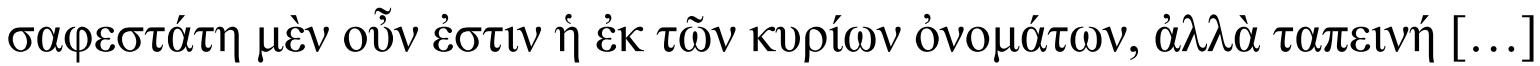

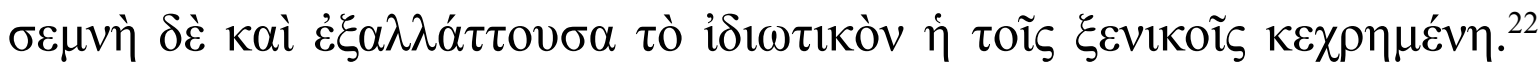

Further on in his discussions Aristotle characteristically decides for a compromise between the use of common and uncommon vocabulary and suggests - to use a rather colloquial statement - a little bit of this and a little bit of that, provided that the rules of decorum are preserved. In his opinion various kinds of words should be properly combined, which would save the language from commonness and vulgarity, which the use of common vocabulary would add clarity: $\delta \varepsilon \tilde{\imath} \not \alpha \rho \alpha \kappa \varepsilon \kappa \rho \tilde{\alpha} \sigma \theta \alpha i$

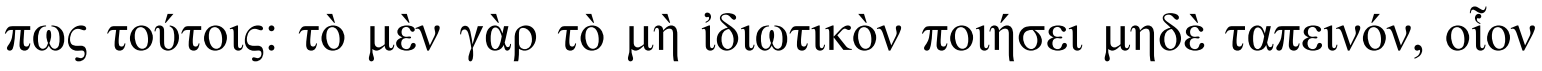

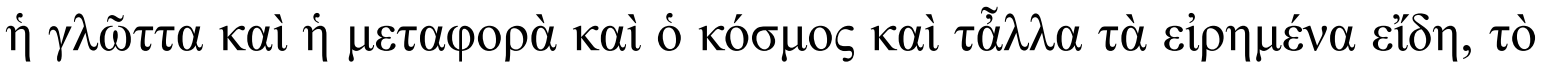

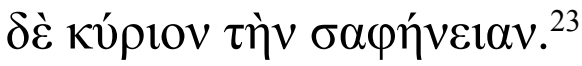

What Aristotle means here goes beyond proper use of both lexical spheres on a syntactic level, resulting from including them in a poetic phrase: the concept also covers proper choice of words, which are built so that they include both the common and uncommon elements:

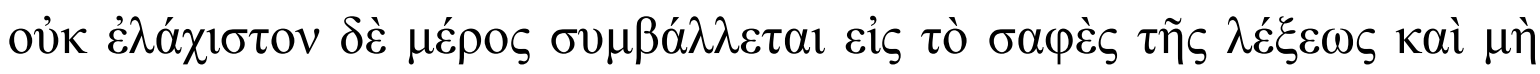

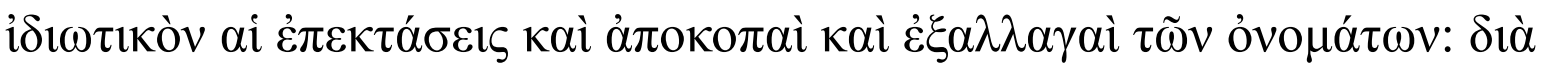

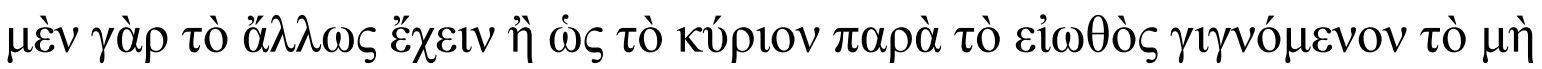

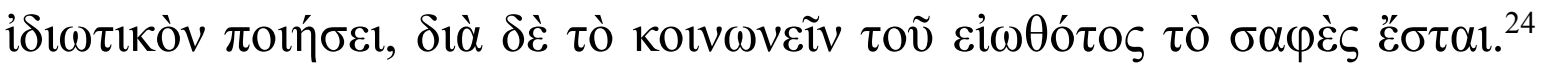
Thus the lexical clarity is enhanced.

I have already stated that the interrelations between the spheres of common and sublime vocabulary are regulated by the aesthetic principle of decorum and the so called relativisations. The task of the speechwriter is to adjust the style of the speech to the person presenting it so that the speaker's age, origin and social status, as well as the matter discussed, were included. According to Aristotle the clear style ( $\left.\lambda \varepsilon^{\prime} \xi 1 \zeta \sigma \alpha \varphi \eta ́ \varsigma\right)$ equals

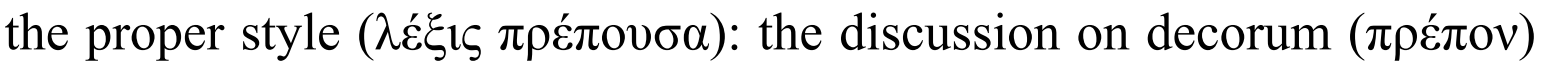

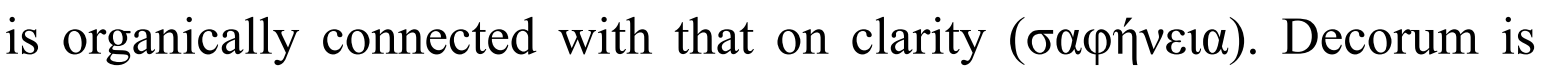
a cause for the speaker to avoid all artificiality and the feeling that he is slavishly following some defined artistic rules. Aristotle devotes the entire Chapter 3 of book III of the Rhetoric to the concept of artificiality and of excessive use of poetic style. He treats them as a serious mistake

\footnotetext{
22 See Aristot. Poet. 22, 1458a, 18-22.

23 See Aristot. Poet. 22, 1458a, 31-34.

$24 \quad$ See Aristot. Poet. 22, 1458a, $34-1458$ b, 5.
} 
and an offence against the rules of both decorum and clarity, threaten-

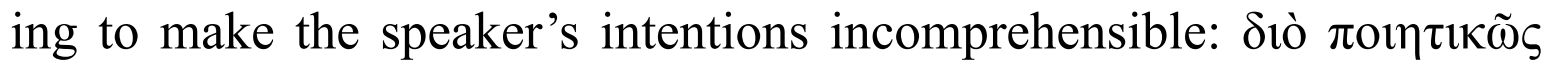

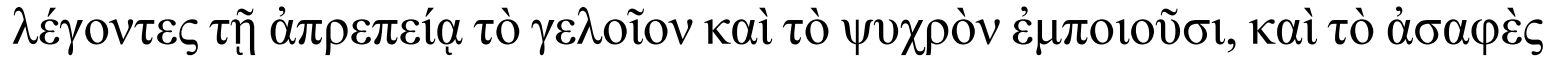

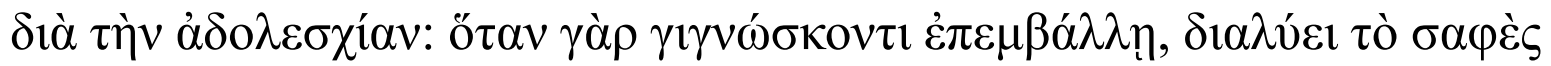

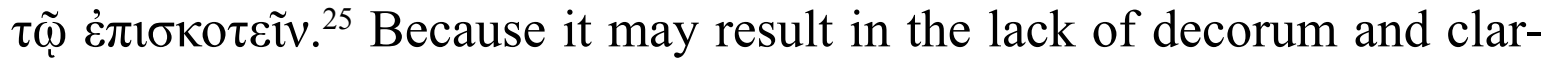
ity, Aristotle warns against too liberal use of the means of expression that he had discussed in the Poetics. He has in mind mainly the glosses, compound words and neologisms, which may tend towards excess and

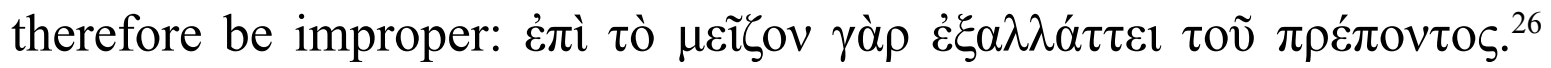
At the same time he makes sure to add, as an embellishment for common words ( $\kappa$ ṕ $\alpha$ ỏvó $\mu \alpha \tau \alpha$ ), metaphor, which is, importantly, used also

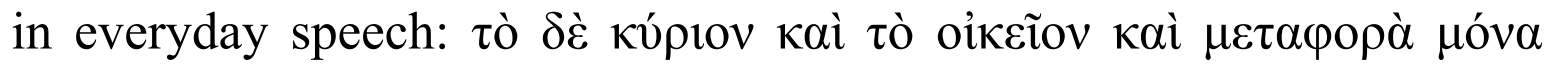

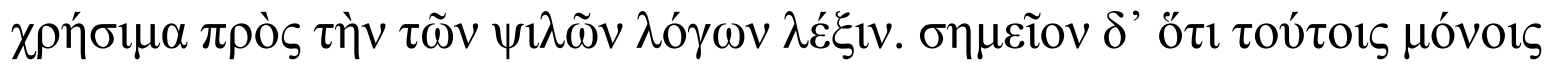

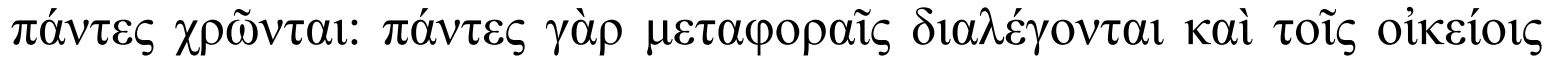

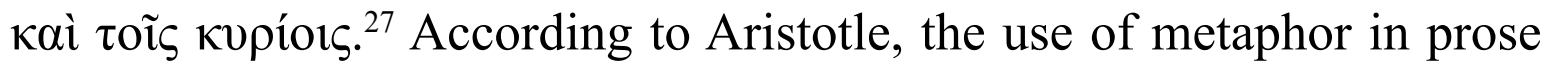
adds to the clarity of the speech and is a source of important artistic effects, evoking feelings of elegance, refinement and subtlety: $\tau$ oбov́ $\tau \omega$

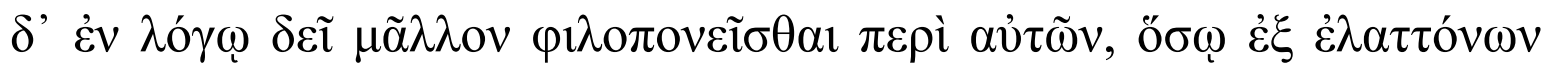

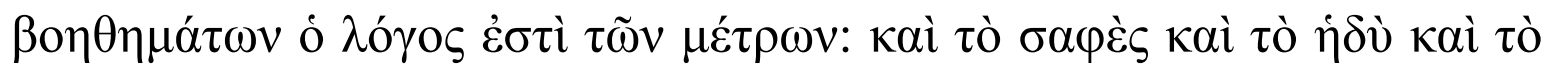

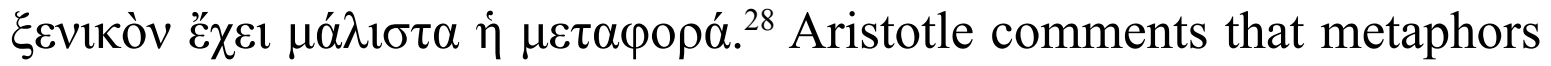
should be created using not the terms whose meanings are distant from each other, but quite the opposite, the ones with similar and homogenous meanings, because thus new and clear names for yet unnamed phenomena might be created. ${ }^{29}$ Metaphors can, actually, themselves be unclear, if they deal with entities too distant from one another: $\alpha \sigma \alpha \varphi \varepsilon i \bar{\varsigma} \delta \dot{\varepsilon}$, $\alpha v$ $\pi$ ó $\rho \omega \theta \varepsilon v .^{30}$

The lack of clarity can also be a result of using in rhetorical speech brief discourse based on the common knowledge shared by the listeners and functioning as communis opinio. These problems are discussed by Aristotle in his theory of enthymeme ( $\tau$ ò $\dot{v} v \theta u ́ \mu \eta \mu \alpha$ ) in books I and II of the Rhetoric. Following Aristotle the enthymeme is defined as a specific

25 See Aristot. $R h$. III 3, 1406b, 32-35.

26 See Aristot. $R h$. III 2, 1404b, 31-32.

27 See Aristot. Rh. III 2, 1404b, 31-33. See also Wood 2015: 104ff; Silk 1969.

28 See Aristot. $R h$. III 2, 1405a, 6-9.

29 See Aristot. $R h$. III 2, 1405a, 34-37.

$30 \quad$ See Aristot. $R h$. III 3, 1406b, 8-9. 
way of deduction in which some of the general elements - the prem-

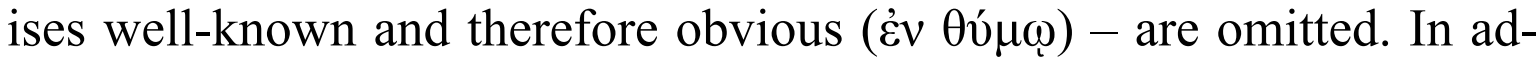
dition this is caused partially by the need to achieve the economy of

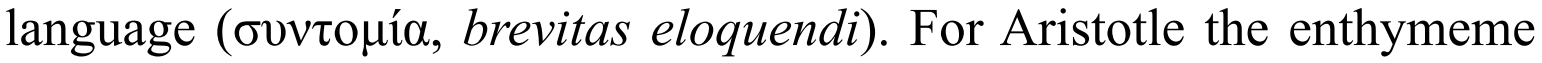
is a kind of dialectic or rhetorical syllogism; in the rhetorical sense it is close to the concept of the topos, because it enables generating

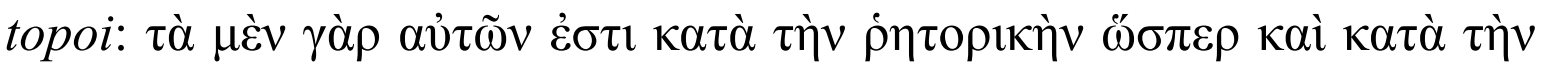

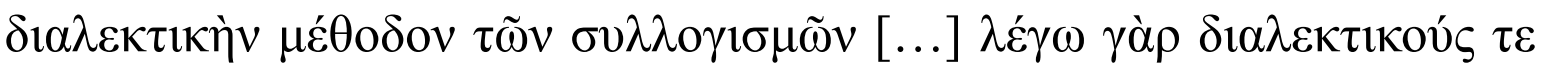

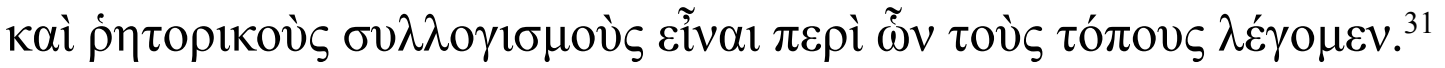

The use of enthymemes is regulated, according to Aristotle, by the rules of decorum, because of the need to preserve clarity (in the case of enthymemes, using too diverse general knowledge) and to avoid garrulity (inference without the use of enthymeme, based on the entire collected

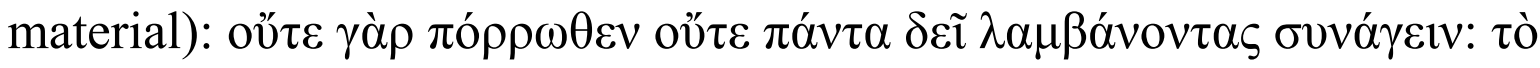

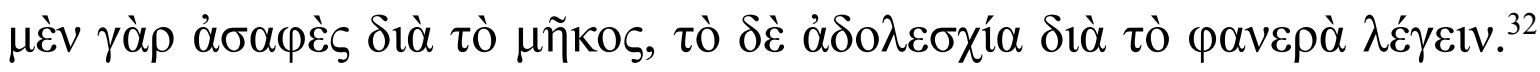

Aristotle's diverse and multifaceted debate on the issue of clarity could be aptly summed up by his statement from Book III of Rhetoric. It has been formulated in relation to rhetorical style but it is general enough to be used for the poetic style as well. In the final part of his discussion on the aesthetics of metaphor in rhetorical style Aristotle states that the style of a good writer should be elegant, discreet and at the same time clear and that these virtues are the key concepts in defining perfect rhetori-

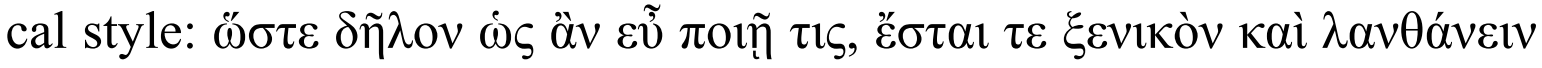

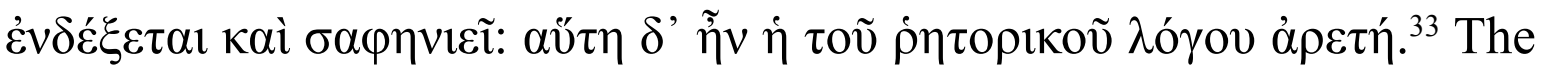
key category here is certainly clarity. Other virtues, such as discreet elegance, are used to emphasize clarity: all the means of expression that do not enhance clarity, contravene the main task of the speech, which is the

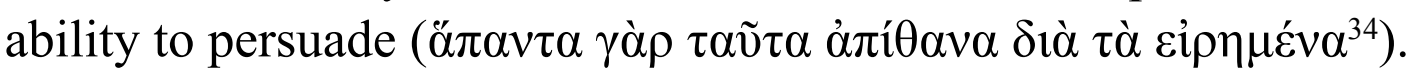

Aristotle's ideas concerning stylistic clarity defined the means of understanding this concept by the next generations of rhetoric and poetic theorists. Aristotle's disciple and successor at the Lyceum, Theophrastus, collected and organized his master's teachings on the virtues of

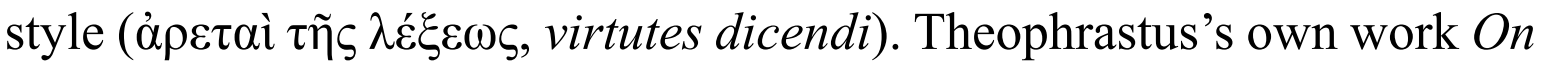

See Aristot. Rh. I 2, 1358a, 4-6; 10-12.

See Aristot. Rh. II 22, 1395b, 24-27.

See Aristot. Rh. III 2, 1404b, 35-37.

See Aristot. Rh. III 3, $1406 \mathrm{~b}$. 
style ( $\pi \varepsilon \rho i ̀ \lambda \dot{\varepsilon} \xi \varepsilon \omega \varsigma)$ has been lost, but we have Cicero's testimony on it, presented in Orator. While characterizing the Attic style (understood as simple and unadorned, yet elegant and refined, despite avoiding all false trumpery and cosmetic additions and preserving only subtlety and urbanity ${ }^{35}$ ) Cicero states: Sermo purus erit et Latinus, dilucide planeque dicetur, quid deceat circumspicietur; unum aberit, quod quartum numerat Theophrastus in orationis laudibus: ornatum illud, suave et adfluens. ${ }^{36}$ This testimony is of crucial importance for the development of the Greek theory of rhetorical style. Cicero names firstly the correctness of the language (sermo purus et Latinus); his term, Latinitas, is the equivalent of Theophrastean $\dot{\varepsilon} \lambda \lambda \eta v i \sigma \mu o ́ \zeta$, and earlier $\tau$ ò $\dot{\varepsilon} \lambda \lambda \eta v i ́ \zeta \varepsilon ı v$, used by Aristotle.

For both philosophers the correctness of language is a primary and

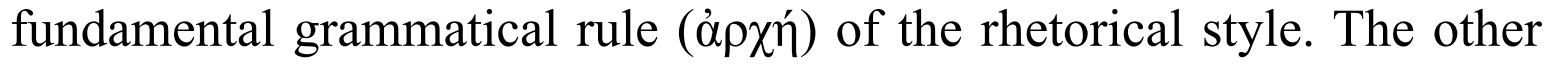
rhetorical virtues, the first amongst which according to both Theophrastus and Aristotle is clarity (dilucide planeque dicetur. explanatio, perspi-

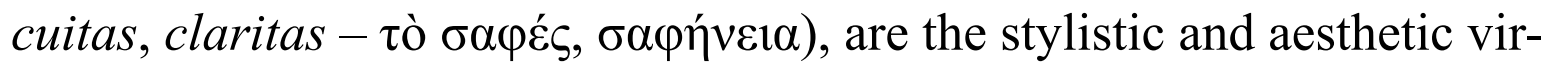
tues of the elocution. The rest of the virtues are propriety (quid deceat;

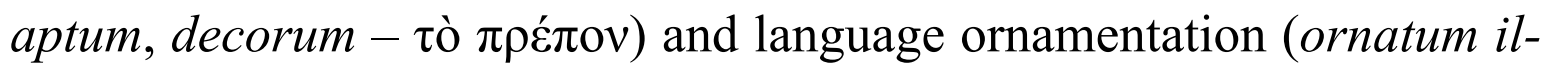

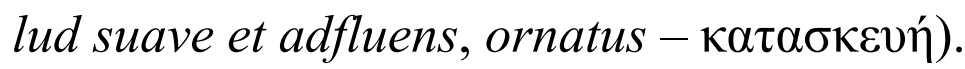

In his own list of the virtutes dicendi, to be found in the speech of Lucius Licinius Crassus in the dialogue De oratore, Cicero slightly modifies the order of the virtues; this change, however, does not affect the place of clarity: quinam igitur dicendi est modus melior [...] quam ut Latine, ut plane, ut ornate, ut ad id, quodcumque agetur, apte congruenterque dicamus. ${ }^{37}$ Decorum was placed last here, probably due to the belief, shared by both Cicero and Aristotle, that it constitutes a specific mechanism regulating both the means to achieve clarity and the range of stylistic embellishments. Crassus has spoken in similar vein already once before, in the part of book devoted to the elements of an ideal speaker's personality. ${ }^{38}$

35 See Cic. Orat. 78-79: Tum removebitur omnis insignis ornatus quasi margaritarum, ne calamistri quidem adhibebuntur, fucati vero medicamenta candoris et ruboris omnia repellentur; elegantia modo et munditia remanebit.

$36 \quad$ See Cic. Orat. 79. Cf. also Stroux 1912: $19 \mathrm{ff}$.

$37 \quad$ See Cic. de Orat. III 37.

38 See Cic. de Orat. I 144: Audieram etiam quae de oratione ipsius ornamentis traderentur: in qua praecipitur primum, ut pure et Latine loquamur, deinde ut plane et dilucide, tum ut ornate, post ad rerum dignitatem apte de quasi decore. 
A similar treatment of clarity can be found in the treatise called Rhetorica ad Herennium. Its anonymous author discusses the features of the perfect art of speaking (quas res debeat habere elocutio commoda et perfect $a^{39}$ ) and names three such qualities: elegance, composition and sublimity tres res in se debet habere: elegantiam, compositionem, dignitatem..$^{40}$ Elegance causes every thing to be pronounced clearly and plainly: Elegantia est, quae facit, ut unum quidque pure et aperte dici videatur. ${ }^{41}$ This quality is attributed to the proper use of language and to clear explanation: Haec tribuitur in Latinitatem et explanationem. ${ }^{42}$ Language remains clear due to its pure and proper form. Mistakes can be avoided thanks to a good command of grammar: Latinitas est quae sermonem purum conservat ab omni vitio remotum. [...] Haec qua ratione vitare possimus, in arte grammatica dilucide dicemus. ${ }^{43}$ At the same time clarity (explanatio) makes the speech clear and understandable: it is achieved by the use of common and proper nouns (the Aristotelian $\kappa v \rho \imath \alpha$ óvó $\mu \alpha \tau \alpha)$ : Explanatio est, quae reddit apertam et dilucidam orationem. Ea comparatur duabus rebus, usitatis verbis et propriis. ${ }^{44}$ The verba usitata come from the everyday sphere of life, while the verba propria are related to the theme of the speech: Usitata sunt ea, quae varsantur in sermonis consuetudine cotidiana; propria, quae eius rei verba sunt aut esse possunt, qua de loquemur. ${ }^{45}$

Cicero treats both these categories, grammatical correctness and clarity, as obvious and necessary qualities which everyone should have no difficulty understanding and which require no explanation. Nevertheless, he makes his interlocutor, Lucius Licinius Crassus, deliver an entire lecture on these two virtues. He states that the first of them should be acquired already in childhood, when one learns to write. The second, conversely, is necessary for a person to be understood:

\footnotetext{
39 See Rh. ad Her. IV 17.

$40 \quad$ See Rh. ad Her. IV 17.

41 See Rh. ad Her. IV 17.

42 See Rh. ad Her. IV 17.

43 See Rh. ad Her. IV 17.

44 See Rh. ad Her. IV 17.

$45 \quad$ See Rh. ad Her. IV 17.
} 
atque eorum quidem, quae duo prima dixi, rationem non arbitror expectari a me puri dilucidique sermonis. Neque enim conamur docere eum dicere, qui loqui nesciat; nec sperare, qui Latine non possit, hunc ornate esse dicturum; neque vero qui non dicat quod intellegamus, hunc posse quod admiremur dicere. Linquamus igitur haec, quae cognitionem habent facilem, usum necessarium. Nam alterum traditur litteris doctrinaque puerili, alterum adhibetur ob eam causam, ut intellegatur, quid quisque dicat; quod videmus ita esse necessarium, ut tamen eo minus nihil esse possit. ${ }^{46}$

Following this confident statement, Crassus makes a long speech on what should be avoided in order to preserve the correctness of language.

Let us, however, return to the category of clarity. To present it, Cicero uses a strategy similar to that applied in the case of grammatical correctness. Firstly, he states that it is not necessary to discuss the second basic quality, because - as suggested by the context - no one has any doubts about the necessity of its use. Later on, however, he starts giving the reader quite detailed advice, returning to the problem of quality also further in the text. Continuing the passage quoted before, Cicero states:

Latine scilicet dicendo, verbis usitatis ac proprie demonstrantibus ea, quae significari ac declarari volemus, sine ambiguo verbo aut sermone, non nimis longa continuatione verborum, non valde productis iis, quae similitudinis causa ex aliis rebus transferuntur, non discerptis sententiis, non praeposteris temporibus, non confusis personis, non perturbato ordine. $^{47}$

Just like the author of the Rhetorica ad Herennium, Cicero sees the need to use the verba usitata ac propria to achieve the virtue of clarity. He warns against the use of unclear statements (the concept of perspicuitas in verbis singulis), but at the same time he is conscious of the syntactic aspect of the problem (perspicuitas in verbis coniunctis), too long rhetorical periods and the need to preserve both internal harmony within the logical and temporal structure of the speech as well as its

$46 \quad$ See Cic. de Orat. III 38.
$47 \quad$ See Cic. de Orat. III 49. 
inner order. His advice includes a warning against metaphors lacking clarity, resulting in allowing too much of a semantic distance between the things encompassed by the metaphor, something that already Aristotle warned rhetoricians against.

The problem of the use of proper vocabulary, crucial for the above passage, as well as the problem that I called the aesthetics of metaphor are discussed in great detail in the latter part of the treatise. When answering to the appeal of Publius Sulpicius Rufus, who suggests the return to problems concerning clarity and perfection of the speech (quae ad ipsius orationis laudem splendoremque pertinet ${ }^{48}$ ), Crassus states that this perfection relies on both the use of proper words and their proper combination: omnis igitur oratio conficitur ex verbis, quorum primum nobis ratio simpliciter videnda est, deinde coniuncte. Nam est quidem ornatus orationis, qui ex singulis verbis est, alius qui ex continuatis coniunctisque constat. ${ }^{49}$ To achieve this goal one should use the proper, common lexical items (verba propria, certa vocabula) - their use and their understanding is certain and results from a kind of custom, since these names are believed to have emerged together with the names that they denote. The other option is to utilize metaphors or neologisms:

ergo utimur verbis aut iis, quae propria sunt et certa quasi vocabula rerum, paene una nata cum rebus ipsis; aut iis quae transferuntur et quasi alieno in loco conlocantur, aut iis, quae novamus et facimus ipsi. ${ }^{50}$

The question of verba usitata and their use has been discussed earlier; here one can only add that Cicero warns against the use of obsolete and forgotten words, while suggesting using chosen and clear words. He also adds a new, previously unmentioned feature: the application of euphonic qualities. It is better to use well-sounding words and always include the famous Ciceronian quality of aurium iudicium..$^{51}$

\footnotetext{
$48 \quad$ See Cic. de Orat. III 147.

$49 \quad$ See Cic. de Orat. III 149.

$50 \quad$ See Cic. de Orat. III 149.

$51 \quad$ See Cic. de Orat. III 150: In propriis igitur est verbis illa laus oratoris, ut abiecta atque obsoleta fugiat, lectis atque inlustribus utatur, in quibus plenum quiddam et sonans inesse videatur. Sed in hoc verborum genere propriorum dilectus est habendus
} 
It is also worth to include into the discussion Cicero's concept of metaphor, which he, just like Aristotle, considered a crucial concept for achieving the clarity of speech. ${ }^{52}$ Cicero discusses metaphors in Book III of De Oratore, making Lucius Licinius Crassus the speaker. ${ }^{53}$ He stresses the great importance of using metaphorical vocabulary: according to Cicero, metaphors were first born out of the poverty of early language and the narrowness of word meanings; later on, when language was developing, these reasons for using metaphors were replaced with pleasure in and predilection for such means. Crassus emphatically states that even simple peasants use metaphors and adds some examples, ${ }^{54} \mathrm{such}$ as 'joyous fields' or 'richness of harvest'. Metaphor, continues Crassus, allows to clarify things that are difficult to present using only proper words (verbum proprium). Let me quote a longer passage here, since it is of crucial importance for the entire concept of claritas: quod enim declarari vix verbo proprio potest, id translato cum est dictum, inlustrat id quod intellegi volumus eius rei, quam alieno verbo posuimus, similitude. ${ }^{55}$ Cicero, like the Aristotelian tradition before him, treats metaphor as a form of shortened comparison: Similitudinis est ad verbum unum contracta brevitas. Quod verbum in alieno loco tamquam in suo positum, si agnoscitur, delectat; si simile nihil habet, repudiatur. ${ }^{56}$

Such an understanding of metaphor has been contested by modern linguistics, where the main argument is that not every metaphor can be turned into a comparison. It is also often stated that in the case of comparison the area of similarity is clearly defined, unlike in metaphor. In the $20^{\text {th }}$ century the theory of metaphor has been tackled by the most prominent linguists, from Roman Jakobson to Claude LéviStrauss, Gareth Morgan, and cognitive linguists such as George Lakoff

\footnotetext{
quidam atque is aurium quodam iudicio ponderandus est; in quo consuetudo etiam bene loquendi valet plurimum.

$52 \quad$ See Calboli 2007: 123ff.

53 See Psaty 1978.

$54 \quad$ See Cic. de Orat. III 155: Tertius ille modus transferendi verbi late patet, quem necessitas genuit inopia coacta et angustiis. Post autem delectatio iucunditasque celebravit. [...] Nam 'gemmare vitis', 'luxuriem esse in herbis', 'laetas segetes'etiam rustici dicunt.

$55 \quad$ See Cic. de Orat. III 155.

56 Cf. Cic. de Orat. III 157. Similarly later in: Quint. Inst. VIII 6, 8: in totum autem metaphora brevior est similitudo.
} 
and Mark Johnson; their work has put metaphor in the centre of human communication. ${ }^{57}$

While continuing to discuss metaphor, Cicero postulates the use in a speech only of those metaphors that are clear and thus make the subject matter clear. ${ }^{58}$ As an example he quotes a passage from a tragedy by Pacuvius (most probably from his play Teucer) that describes a storm at sea. The metaphors based on comparisons used here clarify the situation described. Cicero states that everything that was described there was pronounced with the use of comparison-based metaphors which makes the text clear: omnia fere, quo essent clariora, translatis per similitudinem verbis dicta sunt. ${ }^{59}$ When trying to discover the reasons for the popularity of metaphor, the writer mentions, among other reasons, its sensual character, stressing especially the role of sight, the strongest of the senses: vel quod omnis translatio quae quidem sumpta ratione est, ad sensus ipsos admovetur, maxime oculorum, qui est sensus acerrimus. ${ }^{60}$ Cicero notices that many metaphors allude in their figurative part to various senses: e.g. the smell of urbanity ('odor' urbanitatis), the softness of civilized behaviour ('mollitudo' humanitatis), the whisper of the sea ('murmur' maris), sweetness of speech ('dulcitudo' orationis), but the ones alluding to the sense of sight are the strongest ones, because they make objects and ideas which we cannot see appear before the mind's eye.$^{61}$ It is a beautiful example of verbal vividness (evidentia,

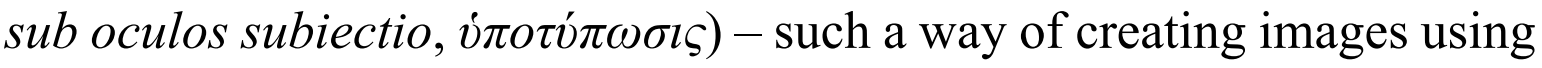
metaphorical language that makes the audience think that they can see the object described. It was a figure of immense popularity in ancient epideictic rhetoric as well as in the mannerist poetry of late Roman antiquity. ${ }^{62}$ According to Cicero using metaphors in order to demonstrate

\footnotetext{
$57 \quad$ See Lakoff, Johnson 1988.

$58 \quad$ See Cic. de Orat. III 157: sed ea transferri oportet quae aut clariorem faciunt rem.

$59 \quad$ See Cic. de Orat. III 157.

60 See Cic. de Orat. III 160.

61 See Cic. de Orat. III 161: nam et 'odor' urbanitatis et 'mollitudo' humanitatis et 'murmur' maris et 'dulcitudo' orationis sunt ducta a ceteribus sensibus; illa vero oculorum multo acriora, quae paene ponunt in conspectu animi, quae cernere et videre non possumus.
}

62 See Zanker 1981; Marini 2018; Bell, Swenson-Wright, Tybjerg 2008; Gorzkowski 2001. 
objects clearly becomes a universal feature, because the verbal statement becomes a total metaphor:

nihil est enim in rerum natura, cuius nos non in aliis rebus possimus uti vocabulo et nomine. Unde enim simile duci potest - potest autem ex omnibus - indidem verbum unum, quod similitudinem continent, translatum lumen adferre orationi ${ }^{63}$

Cicero underlines the fact that as far as singular words are concerned (in singulis verbis) metaphor is the greatest way of adding clarity to a speech. ${ }^{64}$ Later on, while discussing the virtues of style connected with the use of singular words, Cicero stresses, in even more grandiose words, the role of metaphor (verbum translatum), which, like a shining star, throws light at a speech and clarifies it. In this case he means allegory, whose affinity with metaphor was strongly stressed in antiquity: nam illud, quod ex hoc genere profluit, non est in uno verbo translato, sed ex pluribus continuatis conectitur, ut aliud dicatur, aliud intelligendum sit. ${ }^{65}$ Cicero believes allegory to be a great adornment for a speech, but at the same time he advises its cautious use, in order to avoid the lack of clarity and not to change the speech into a riddle. The question of obscurity in speech (obscuritas, $\dot{\alpha} \sigma \alpha ́(\varphi \varepsilon 1 \alpha$ ) has been broadly discussed by both Aristotle and Cicero. Let me quote here just a number of the latter's statements concerning the topic. One of them deals with the style of judicial oratory preferred by Lucius Fufius and Gnaeus Pompeius, plebeian tribunes in the years 91-90 BC. The character of Crassus discusses the clarity of judicial speeches and decides that sometimes the way a client presents his case is clearer that what later a lawyer has to say. As an example of obscurity he cites the speeches of both tribunes. His list of charges is quite serious: the lack of internal order, grave mistakes in the disposition of the speech, and improper and exaggerated vocabulary - all resulting in the general feeling of chaos and obscurity:

\footnotetext{
$63 \quad$ See Cic. de Orat. III 161.

$64 \quad$ See Cic. de Orat. III 166: Modus autem nullus est florentior in singulis verbis neque qui plus luminis adferat orationi.

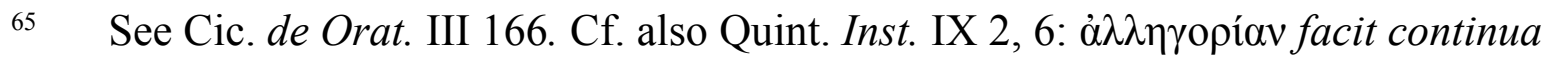

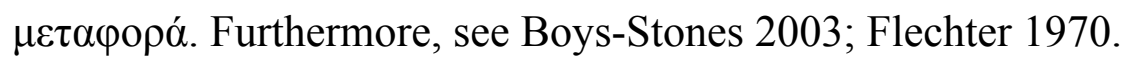


easdem res autem simulac Fufius aut vester aequalis Pomponius agere coepit, non aeque quid dicant, nisi admodum attendi, intellego; ita confusa est oratio, ita perturbata, nihil ut sit primum, nihil ut secundum, tantaque insolentia ac turba verborum, ut oratio, quae lumen adhibere rebus debet, ea obscuritatem ac tenebras adferat atque ut quodam modo ipsi sibi in dicendo obstrepere videantur. ${ }^{66}$

Cicero discusses in detail the problem of clarity in judicial speeches in Book II of De Oratore, making the character of Marcus Antonius (the grandfather of the future triumvir) the speaker. Antonius stresses the need of transparent clarity in the second segment of a speech, the one called narratio and used to present the case and narrate it. He emphasises the fact that all other parts of the speech beside the narratio (exordium, argumentatio, [refutatio], conclusio) also require clarity, but it is of crucial importance to be clear in the presentation of the case: it is more difficult to achieve and the lack of clarity in this particular part of the speech makes the entire composition unclear (difficult to understand), while the obscurity of other parts causes the lack of understanding only, so to say, of local importance, i.e. pertaining to the things said then and there. ${ }^{67}$ The question of clarity in presenting the speech is in fact based on the use of common vocabulary (verba usitata), the proper keeping of chronological order (ordo temporum) and uninterrupted narrative (si non interrupte narrabitur). ${ }^{68}$

Cicero is interested in one more aspect of achieving clarity in the narratio: the one related intrinsically to the brevity of speech (brevitas eloquendi). Earlier, Marcus Antonius, while discussing the divisions within the art of speech and the orations themselves, mentions three main virtues of the narratio: probability, clarity and brevity: ut veri similis narratio sit,

\footnotetext{
$66 \quad$ See Cic. de Orat. III 50.

67 See Cic. de Orat. II 239: apertam enim orationem tam esse oportet quam cetera, sed hoc magis in hac elaborandum est, quod et difficilius est non esse obscurum in re narranda quam aut in principio aut in argumentando aut in perorando et maiore etiam periculo haec pars orationis obscura est quam cetera, vel quia, si quo alio in loco est dictum quid obscurius, tantum id perit, quod ita dictum est, narratio obscura totam occaecat orationem.
}

$68 \quad$ See Cic. de Orat. II 239. 
ut aperta, ut brevis. ${ }^{69}$ The demand for brevity as a normative recommendation is stated by Cicero already at the beginning of his discussion on presenting the case in judicial speech: Narrare vero rem breviter iubent, si brevitas est apellanda, cum verbum nullum redundant.$^{70}$ Brevity is in the service of clarity, but at the same time an orator must be cautious, because excessive brevity becomes a source of obscurity and misunderstanding; moreover, it takes away the audience's pleasure, the source of which would be listening to a more artfully devised presentation. It also often renders a speech less convincing.

The problems of brevity and clarity of style allow us to address Horace's opinion presented in the Ars poetica. The poet, when discussing his artistic aims, states: Quidquid praecipies, esto brevis, ut cito dicta / percipiant animi dociles teneantque fideles. ${ }^{71}$ In the case of clarity and brevity, however, Horace is aware of the dangers, similar to those discussed by Cicero: brevis esse laboro, obscurus fio. ${ }^{72} \mathrm{He}$ is also convinced that a properly chosen poetic topic would provide both eloquence and a clear order of things (lucidus ordo)..$^{73}$

Numerous testimonies on the problem of clarity, presented in the paper and dealing with the category of clarity as an aesthetic virtue of artistic prose stress its special position among the commonly accepted stylistic values. The ideas of Plato are a starting point for clarity as a result of either the use of properly chosen singular words (in verbis singulis) or the proper combination thereof (in verbis coniunctis). We have mentioned that Aristotle clarified the basic normative rules of clear style

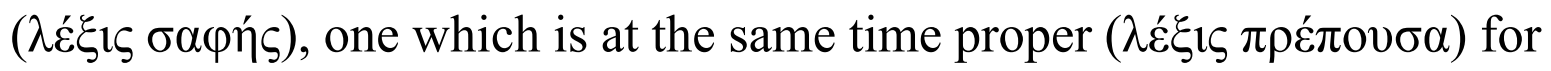
both rhetoric and poetry. He has also elaborated on the topic of the clarity as a result of the proper choice of vocabulary ( $\kappa \dot{\rho} \rho \alpha$ óvó $\mu \alpha \tau \alpha$ ) in poetry and prose, stressing, however, also the need to use other kinds of words, the ornate and unusual ones, which are as a rule, used in poetry; the rule of propriety ( $\pi \rho \varepsilon \dot{\pi} \pi v)$, however, must always be observed. Such vocabulary has its place in the prosaic style, as it helps to avoid the feeling of ordinary commonness.

69 See Cic. de Orat. II 80. Similarly in: Rh. ad Her. I 14 (verisimilis, dilucida, brevis).

70 See Cic. de Orat. II 326.

71 See Hor. Ars 335-336.

72 See Hor. Ars 25-26.

73 See Hor. Ars 40-41. 
Generally, the aesthetic rule of decorum ( $\pi \rho \varepsilon \dot{\pi} \pi \mathrm{\nu})$ is omnipresent in Aristotle's discussion of the quality of clarity; it is a special regulatory mechanism, used to moderate the artistic actions of a poet or a speaker. It applies not only to observing clarity, but also to every other stylistic feature, such as ornate language, avoiding artificiality, the aesthetics of metaphor or solving the problems of brevity and conciseness. Thanks to Cicero's statement in Orator we are aware of the opinion of Theophrastus and of his rules which become a staple for the next generation of Roman theoreticians, especially the anonymous author of the Rhetorica ad Herennium, Cicero, as well as Horace, together with a veritable host of later grammarians and rhetoricians not discussed in the present paper. Among those quoted here, the role of Cicero is crucial in defining clarity and providing ways to achieve it. Generally he follows the ideas of Aristotle, and offers a detailed discussion of the issue of clarity in verbis singulis according to Aristotelian norms. Here of special importance is the problem of common versus ornate vocabulary, a long discussion on the aesthetics of metaphor as a stylistic feature aimed at achieving clarity and vividness of the language, as well as the ideas of total metaphor and brevitas eloquendi. Furthermore, Cicero includes the sphere of clarity in verbis coniunctis - he criticizes the unnecessary lengthening of the period and constructing allegories. At the end of the paper we briefly mentioned the concepts of Horace and his take on the relations between brevitas and obscuritas as well as the need to adjust properly the poetic material, providing for proper eloquence and clear division of topics.

\section{BIBLIOGRAPHY}

Bell A., Swenson-Wright J., Tybjerg K. (ed.), 2008, Evidence, Cambridge University Press.

Boys-Stones G. R. (ed.), 2003, Metaphor, Allegory and the Classical Tradition. Ancient Thought and Modern Revision, Oxford, [online:] http://dx.doi. org/10.1093/acprof:oso/9780199240050.001.0001.

Calboli G., 2007, 'The Metaphor after Aristotle', [in:] Influences on Peripatetic Rhetoric: Essays in Honour of William W. Fortenbaugh, D. C. Mirhady (ed.), Leiden, pp. 123-150. 
Diels H., 1934, Die Fragmente der Vorsokratiker, Vol. I, $5^{\text {th }}$ ed., Berlin.

Fletcher A., 1970, Allegory. The Theory of the Symbolic Mode, Cornell University Press.

Gorzkowski A., 2001, “Ut pictura verba': zagadnienie unaocznienia w retoryce starożytnej i wczesnonowożytnej', Pamiętnik Literacki 92/2, pp. 37-59.

Lakoff G., Johnson M., 1988, Metafory w naszym życiu, transl. T. P. Krzeszowski, Warszawa.

Lausberg H., 2002, Retoryka literacka. Podstawy wiedzy o literaturze, transl., ed. and introd. A. Gorzkowski, Bydgoszcz.

O’Callaghan J., SJ, 1960, Las tres categorías estéticas de la cultura clásica. Armonía, claridad, grandeza, Madrid.

Psaty B. M., 1978, 'Cicero's Literal Metaphor and Propriety', [in:] Central States Speech Journal 29, pp. 107-117, [online:] http://dx.doi.org/10.1080/ 10510977809367964.

Silk M., 1969, Die aristotelische Theorie der Metapher; ein Versuch ihrer Rekonstruktion, München.

Stroux J., 1912, De Theophrasti dicendi virtutibus, Leipzig.

Styka J., 1997, Estetyka stosowności (decorum) w literaturze rzymskiej, Kraków.

Styka J., 1998, “Convenientia partium': Kategoria harmonii i symetrii w antycznej estetyce literackiej ('Convenientia partium': Harmony and Symmetry in Ancient Literary Aesthetics)', [in:] Prace Komisji Filologii Klasycznej PAU 27, R. Turasiewicz (ed.), Kraków, pp. 29-53.

Styka J., 2008, ‘Sydoniusz Apollinaris i kultura literacka w Galii V wieku’, Kraków. Tatarkiewicz W., 1976, Dzieje sześciu pojęć, Warszawa.

Vatri A., 2017, Orality and Performance in Classical Attic Prose. A Linguistic Approach, Oxford University Press, [online:] http://dx.doi.org/10.1093/ acprof:oso/9780198795902.001.0001.

Webb R., 2009, Ekphrasis, Imagination and Persuasion in Ancient Rhetorical Theory and Practice, Ashgate Publishing Company Farnham.

Wood M. S., 2015, Aristotle and the Question of Metaphor, Ottawa, [online:] http://dx.doi.org/10.20381/ruor-4757.

Zanker G., 1981, 'Enargeia in the Ancient Criticism of Poetry', Rheinisches Museum für Philologie, Neue Folge 124/3/4, pp. 297-311. 